
НАУКОВО-ПЕДАГОГІЧНІ ПІДХОДИ ДО ОРГАНІЗАЦІЇ ПРОЦЕСУ РОЗВИТКУ
МУЗИКАЛЬНОСТІ У МОЛОДШИХ ШКОЛЯРІВ

\title{
SCIENTIFIC AND PEDAGOGICAL APPROACHES TO THE ORGANIZATION OF THE PROCESS OF MUSICAL DEVELOPMENT IN JUNIOR SCHOOLCHILDREN
}

УДК 373.3.091.3:78

DOI https://doi.org/10.32843/2663-

6085/2021/41/1.12

\section{Лі Хуйсран,}

аспірантка кафедри педагогіки мистецтва і фортепіанного виконавства Національного педагогічного університету імені М.П. Драгоманова
У статті розглянуто проблему розвитку музикальності учнів закладів позашкільної спеціалізованої мистецької освіти в прочесі музичного навчання. Розкрито сутність феномена музикальності як якості особистості, що акумулює комплекс спеціальних музичних здібностей у розвиненій здатності емоційного переживання інтонованих смислів музики як мистецтва. Вказується на проєкцію музикальності на різні види музичної діяльності учнів музичних шкіл - сприймання, виконавства, інтерпретації, що притаманна двом першим видам діяльності. Науково-педагогічні підходи проаналізовані як детермінанти для розроблення і впровадження методики індивідуального розвитку музикальності учнів. Виокремлено і розкрито зміст особистісно орієнтованого, аксіологічного, комплексного, художньо-інтегрального, культурологічного, середовищного суб'єктно-діяльнісного підходів. Розвиток музикальності розглянуто через означені підходи в контексті духовного становлення особистості, їі світоглядних орієнтирів, цінностей етичних і мистецьких, здатності художньої комунікації, пріоритетності суб'єктності учня в музичному навчанні. Показано взаємозв'язок означених підходів та їх полічентричну ієрархію в дотриманні задля оптимізації педагогічних впливів на розвиток музикальності учнів. Центрами ієрархії визнано середовищний та суб'єктно-діяльнісний підходи. Аналіз науково-педагогічних підходів позиціоновано як детермінанту для характеристики і вибору змісту, форм, методів, творчих завдань індивідуально для розвитку музикальності кожного учня як унікальної особистості, що зумовлює подальше обірунтування педагогічних принципів та педагогічних умов, які мають забезпечити дієвість методики.

Ключові слова: види музичної діяльності, музикальність, музичне навчання, науково- педагогічні підходи, спеціалізована мистецька освіта, особистісні цінності.

The problem of development of musicality of pupils of establishments of out-of-school specialized art education in the course of musical training is considered in the article. The essence of the phenomenon of musicality as a quality of personality is revealed, which accumulates a complex of special musical abilities in the developed ability of emotional experience of intoned meanings of music as art. The projection of musicality into different types of musical activity of students of music schools is indicated - perception, performance, interpretation, which is inherent in the first two types of activity. Scientific and pedagogical approaches are analyzed as determinants for the development and implementation of methods for individual development of students' musicality. The content of personality-oriented, axiological, complex, art-integral, culturological, environmental and subject-activity approaches is singled out and revealed. The development of musicality is considered through these approaches in the context of the spiritual formation of the individual, his worldview, ethical and artistic values, the ability of artistic communication, the priority of the subject of the student in music education. The interrelation of the mentioned approaches and their polycentric hierarchy in observance for optimization of pedagogical influences on development of musicality of pupils is shown. The centers of the hierarchy substantiate the environmental and subject-activity approaches. Analysis of scientific and pedagogical approaches is positioned as a determinant for characterization and selection of content, forms, methods, creative tasks individually for the development of musicality of each student as a unique personality, which leads to further substantiation of pedagogical principles and pedagogical conditions to ensure effectiveness. Key words: types of musical activity, musicality, musical training, scientific and pedagogical approaches, specialized art education, personal values.
Постановка проблеми у загальному вигляді. Розвиток музикальності особистості постійно перебуває в полі зору практиків музичного навчання дітей, передусім учнів закладів спеціалізованої позашкільної мистецької освіти. Поряд зі з'ясуванням сутності самого феномена музикальності тривають пошуки і дискусії стосовно способів здійснення ефрективного педагогічного впливу на її розвиток. Такі пошуки спрямовані як на обґрунтування методики музичного навчання, в центрі якої постає саме музикальність як особистісна якість учня, так і на з'ясування передумов для результативного впровадження форм, методів, різноманітних педагогічних прийомів і засобів педагогічного впливу на особистість. До таких передумов і належать науково-педагогічні підходи до розроблення відповідної методики та ії ефрективне впровадження в індивідуальне навчання учня як унікально обдарованої в музиці особистості.

Аналіз останніх досліджень і публікацій. Вихідними для заявленої в назві статті наукової розвідки є фрундаментальні психологічні та педагогічні дослідження різних аспектів ореномена музичних здібностей у зіставленні з власне музикальністю (Г. Костюк, О. Леонтьєв, Б. Теплов та інші), теоретичні обґрунтування способів ідентисрікації музикальності, здібностей, обдарованості (Л. Бочкарьов, А. Готсдінер, О. Комаровська, С. Науменко, К. Тарасова та ін.), праці, що висвітлюють загальнопедагогічні проблеми розвитку особистості, становлення ії духовного світу, цінностей, зокрема, в мистецькій сфері (I. Бех, 
Т. Грізоглазова, І. Зязюн, Г. Філіпчук, Н. Чепелєва та ін.). Суттєвим підґрунтям для об'єктивності наукового пошуку стали праці з естетики, мистецтвознавства, психології і педагогіки творчості (А. Козир, Л. Левчук, Лю Ян, Т. Рейзекінд, В. Роменець, Цзя Ян, Г. Шевченко та ін.).

Виділення не вирішених раніше частин загальної проблеми. Дослідники проблеми музикальності і різних аспектів музичного навчання пріоритетну увагу звертають на аналіз сутності явища і методичні аспекти роботи з учнями. Однак майже не акцентується позиція детермінант для розроблення відповідних методичних складників. Але ж такі детермінанти якраз і пояснюють та встановлюють вектори методичних пошуків, оптимізуючи педагогічний вплив на особистість. До таких детермінант і належать, зокрема, науково-педагогічні підходи до розвитку музикальності дитини певного віку.

Мета статті - проаналізувати науково-методичні підходи до розвитку музикальності дитини в музичному навчанні в їхньому взаємозв'язку 3 опертям на френомен музикальності.

Виклад основного матеріалу. В обґрунтуванні і конкретизації науково-педагогічних підходів у контексті музичного навчання, в основу якого покладено розвиток музикальності, відштовхуємось від попередньо здійсненого авторкою статті теоретичного дослідження, в якому було уточнено сутність феномена музикальності на перетині психолого-педагогічного та естетико-мистецтвознавчого векторів стосовно учнів музичних шкіл і в контексті видів їхньої мистецької діяльності [13]. Так, музикальність тлумачимо як синкретичний особистісний феномен, що $є$ інтегральним стосовно музичних здібностей, який виникає як результат глибинного емоційного переживання засобів музичного висловлювання та інтонування смислів музичного твору; безумовно, цей особистісний феномен забезпечується учнями музичної школи насамперед через діяльність виконавства, невід'ємного від сприймання та інтерпретації, охоплює емоційні пізнавальні процеси, психомоторику, мотивацію, креативні прояви, артистизм, сореру особистісних цінностей, загалом музичне мислення і здатність художньої комунікації Науково-педагогічні підходи до розвитку музикальності і мають скласти методичне підґрунтя для впливу на кожен з аспектів френомена музикальності, що і розглянемо далі.

Так, виходячи 3 аналізу феномена музикальності, вбачаємо логічною опору на такі науковопедагогічні підходи, як особистісно орієнтований, аксіологічний, комплексний, художньо-інтегральний, культурологічний, середовищний, суб'єктнодіяльнісний. А саме:

- особистісно-орієнтований підхід враховує самоцінність і унікальність особистості та самобутність її творчості невід'ємно від поступового становлення самої особистості. Адже «смисл і ціль освіти - людина у постійному розвитку, іiї духовне становлення, гармонія іії відносин із собою і іншими людьми, зі світом» [10, с. 14]. Така людина здатна до «самоосмислення та осмислення світу через засвоєння основних культурних дискурсів, розуміння та інтерпретації життєвого досвіду, а також переосмислення, трансорормації власного життєвого досвіду» [15, с. 6]. Як підкреслює І. Бех, розкриваючи сутність особистісно орієнтованого підходу через процес духовного становлення особистості в її русі до вищих цінностей (що суголосно навчанню мистецтва), у дитини в такому сходженні «поволі фрормується тенденція до внутрішньої діяльності, предметом якої виступають різні духовні ситуації <...> Вона таким чином переміщується у вищий духовний план світосприйняття і відповідного діяння» [3, с. 33-34].

Важливою метою педагогічних впливів на особистість є їі здатність творити власне життя, усвідомлюючи себе суб'єктом творення. Навчання мистецтва якнайкраще спонукає до розкриття «Я», виявлення оригінальності художнього мислення, сміливості в інтерпретаціях і $€$ оптимальним для формування успішної позитивно налаштованої особистості. Тобто навчання мистецтва має націлюватись не лише на опанування певних умінь (зокрема, виконавських), а й на «здатність людини виступати автором власного життя, <..> за власними «сценаріями» $[15$, с. 4].

Отже, розвиток музикальності в музичному навчанні невіддільний від загальноособистісного розвитку учнів, їхнього прагнення досконалості як моральної, загально естетичної, так і власне в музичних уміннях. Отже, відзначаємо щільний зв'язок особистісно орієнтованого підходу з аксіологічним, що невіддільний від педагогічного впливу на систему цінностей, причому як художніх (музичних), так і етичних. А оскільки цей вплив відбувається у діяльності, передусім виконавській діяльності учнів та в діяльності комунікації, то, вочевидь, особистісно орієнтований підхід також взаємопов'язаний і $з$ діяльнісним (далі конкретизований як суб'єктно-діяльнісний), і з художньою комунікацією у процесі діяльності;

- аксіологічний підхід означає визнання особистості як цінності та визнання продуктів творчості особистості як цінності. Про роль цінності вже йшлося вище, у контексті розгляду сутності особистісно орієнтованого підходу. Тут додамо: саме поняття цінності, зокрема особистісної цінності, пошук механізмів трансорормації об'єтивних цінностей в особистісні, є стрижневими для мистецької освіти [12]. Базуючись на детальному теоретичному аналізі психологічних і культурологічних джерел, Р. Винничук слушно зауважує, що «система цінностей і ціннісних орієнтацій, які 
емоційно «забарвлюються» у процесі діяльності та визначають ставлення особистості до себе, інших людей і навколишнього світу, є одними з складників духовної культури особистості» [5, с. 94], для якої, у свою чергу, підґрунтям слугує художньоестетична культура.

Саме тому надзвичайно важливим для фрормування музикальності як здатності переживання смислів музики є спрямування педагогічних впливів на ставлення дитини до музики як цінності і до власної музично-виконавської творчості як цінності.

Тобто ще раз підтверджуємо, що аксіологічний підхід невіддільний від особистісно орієнтованого: відповідно до особистісно орієнтованого підходу пошуки методичних засад мають відбуватись індивідуально для кожного учня з урахуванням вихідного підґрунтя - сутності френомена музикальності; натомість аксіологічний підхід $є$ свого роду детермінантою для обґрунтування конкретних методичних способів роботи з учнями-музикантами, тобто для впровадження особистісно орієнтованого підходу; очевидними також є кореспонденції між аксіологічним і суб'єктно-діяльнісним та культурологічним;

- комплексний підхід означає розгляд феномена музикальності як багатоскладового явища, яке виявляє себе в різних видах музичної діяльності - сприйманні, творенні та різного роду інтерпретаційній діяльності, що випливає з тлумачення змісту феномена музикальності;

- художньо-інтегральний підхід виявляється в тому, що феномен музикальності, охоплюючи сукупність різних музичних здібностей та обов'язково - їхнє «злиття» через природну здатність емоційного переживання змісту музики як виду мистецтва, до того ж сам по собі є складником більш широкої цілісності. Зазначимо наприклад, що історії мистецтва відомо безліч фрактів обдарування людини одночасно в різних видах художньої творчості. В основі ж обдарування у кожному виді мистецтва лежить особистісна якість, що подібна до музикальності; тобто, крім відповідних окремих здібностей, ще й обов'язково це здатність загостреного емоційного переживання не лише образності конкретного мистецтва, а і його виражальних засобів [12]. Психологи (Б. Ананьєв [2], А. Готсдінер [7], О. Рудницька [14] та ін.) пов'язують це 3 одночасною полімодальністю здібностей, що зумовлено сенсорною системою людини. Це явище, як відомо, пояснюється синестезією відчуттів: дія певних аналізаторів здатна викликати дію інших аналізаторів [6]. Однак О. Комаровська здійснила пошук на перетині аналізу психологічних та естетико-мистецтвознавчих досліджень і показала, що, крім психологічних пояснень полімодальності здібностей, а отже і музикальності, існує ще й мистецтвознавче пояснення, що лежить у синкретичній природі мистецтва, а отже, у «цілісності сприйняття та інтерпретації мистецтва і світу через мистецтво», що зумовлюється цілісністю самої особистості [12, с. 91].

Посилаючись на низку досліджень (Л. Масол, Ван Яюєці, Т. Голінська, Лю Цяньцянь, Лю Ян, Т. Рейзекінд, Г. Шевченко, Цзя Ян, Б. Юсов та ін.), Ся Гаоян узагальнює, що «інтеграція, що тлумачиться як педагогічний інструмент системного поєднання засобів різних мистецтв у впливі на особистість, зумовлює формування в неї цілісного світовідчуття і не лише забезпечує обізнаність у сорері певного виду мистецтва, а й породжує нову якість погляду на світ мистецтва і світ загалом» [16, с. 6]. Щодо підготовки музикантів учений обґрунтовує доцільність їхньої поліхудожньої підготовки на основі музикоцентричної інтеграції як домінантної завдяки інтонаційній природі музики, яка здатна переносити свою образність на інші мистецтва. На переконання авторки статті, ці висновки логічно проєктуються й на дослідження розвитку музикальності у дітей;

- культурологічний підхід, сутність якого полягає в узагальненому тлумаченні культури як контексту для розуміння світу самої людини, точніше тих сенсів, якими світ наповнений для неї. Культура для сучасної освіти постає і як мета, і як чинник її розвитку [17, с. 20]. Власне, культуротворча фрункція, як відомо, - одна 3 важливих для освіти загалом, а для навчання мистецтва стрижнева. Натомість мистецтво також $€$ багатофункціональним; його культуротворча фрункція виявляється в тому, що воно «здатне не лише утворювати духовні цінності, а й давати їм форми життя в кожну нову епоху» [9].

Як стверджує Г. Філіпчук, процес пізнання культури завжди «безперервно олюднював людину» $[18$, с. 6]. Саме тому, на думку вченого, «прагнення «годуватися» культурою - універсальне у вимірах людського буття, а парадигма - «культура освіта - людина - суспільство - світ» $є$ методологічна база для глобального і національного розвитку» [18, с. 9].

У контексті розвитку музикальності особистості культурологічний підхід важливий тому, що дозволяє скеровувати педагогічні зусилля на розуміння дитиною мистецтва як складника культури, а отже, навчати переживати смисли мистецтва, зокрема музичного, як смисли життя, розвиваючи музикальність як здатність переживання цих смислів у музичних образах.

Таким чином, взаємозв'язок культурологічного підходу з рештою також очевидний;

- середовищний підхід, що є надзвичайно важливим і пов'язаний із тлумаченням освітнього середовища не лише як оточення дитини, а і якпевної рухомої і динамічної активності, що спонукає до активності саму дитину в її саморозвивальному 
русі. Як відомо, освітнє середовище загалом тлумачиться як сукупність чинників, що утворюють систему впливів на особистість, які сприяють (або можуть перешкоджати) їі розвитку, передусім йдеться про можливості соціального та предметного оточення як середовища «безпосереднього та опосередкованого впливу на дитину на макрорівні; сукупність об'єктивних і суб'єктивних фракторів, що створюють умови життєдіяльності особистості, <..> впливає на процес і повноту творчої самореалізації» [1, с. 95]. Розглядаючи феномен середовища стосовно мистецької освіти, О. Комаровська [12] вказує на нього як на провідний психолого-педагогічний механізм утворення цінностей особистості, що базується на емоційному переживанні, а отже, дотично до музикальності особистості. Учена обґрунтовує єдність мистецьких подій та художньо-предметного поля, які взаємодіють лише завдяки діяльності суб'єктів у багатоаспектній художній комунікації і лише в такий спосіб оптимізують досягнення успіху в діяльності. Проекція цієї тези на контекст музикальності учнів дозволяє нам провести паралелі між «мистецькою подією» як структурним елементом середовища та різними етапами і формами роботи над виконавським репертуаром 3 учнями, а також між художньо-предметним полем і методичним, інструментальним забезпеченням освітнього процесу підготовки юних музикантів, передусім, як віддзеркалення або прогнозування події. Спонукання до самопізнання, самовираження, самостійності інтерпретацій тощо одночасно пробуджують в учнів потребу бути суб'єктами навчання музики загалом.

Таким чином, очевидним $є$ взаємозв'язок середовищного підходу з усіма, що були розглянуті, але особливо слід виокремити зв'язок середовищного із наступним, суб'єктно-діяльнісним;

- суб'єктно-діяльнісний підхід означає не лише діяльнісну активність особистості як підґрунтя розвитку, а і її суб'єктність, тобто прийняття особистістю активної позиції щодо себе, своєї творчості, свого позиціонування в суспільстві, своїх можливостей впливати на процеси навколо себе тощо. «Творення себе $€$ найважливішим атрибутом суб‘єкта, що не $є$ пасивним реципієнтом «книги життя», а її активним автором» [15, с. 4].

Слід зазначити, що А. Брушлинський довів нерозривність фрормування суб'єктності і конкретної діяльності, в якій людина виявляє і фрормує свою суб'єктність [4]. Саме активність у діяльності, ініційована суб'єктом цієї діяльності, уможливлює рух особистості до досягнення акме, що вкрай важливо в мистецькій педагогіці і націлює методичні пошуки в тому числі й на способи спрямування учнів на самовираження і самовдосконалення, тобто на конкретизацію акмеологічної стратегії [11].
Власне, на фрормування суб'єктності дитини спрямовані педагогічні дії в контексті особистісно орієнтованого підходу, оскільки особистісно орієнтоване виховання і передбачає насамперед такий тип суб'єкт-суб'єктної взаємодії, в якій домінують власні зусилля особистості [3].

Не викликає сумнівів, що суб'єктність дитини «визріває» в її конкретній діяльності і виявляється в чітко окресленому середовищі, яке учень створює як активний його учасник і стосовно, передусім, своїх запитів щодо його змісту.

Отже, саме ці підходи - середовищний і суб'єктно-діяльнісний - можемо вважати рівнозначно стрижневими в процесі педагогічного планування і організації розвитку музикальності учнів у закладі позашкільної музичної освіти. Решту підходів можемо позиціонувати як такі, що увійшли в контекст суб'єктно-діяльнісного та середовищного як взаємозумовлені з ними і між собою, сукупно утворюючи ієрархічну систему.

Висновки. Виокремлюючи науково-педагогічні підходи в проекції на розвиток музикальності дитини в музичному навчанні, фріксуємо, по-перше, взаємозв'язок їхнього змісту в детермінації методичних пошуків; по-друге, все ж вбачаємо доцільність вибудувати певну ієрархію розглянутих підходів, серед яких логічно визначаються два центри - середовищний і суб'єктнодіяльнісний підходи як інтегральні стосовно інших. Натомість розглянуті науково-педагогічні підходи слід позиціонувати як важливий, але не єдиний чинник створення методичного підґрунтя для музичного навчання дітей, спрямованого на розвиток музикальності. Поряд мають бути вивченні й інші складники, передусім стрижневі педагогічні принципи для організації та змістового наповнення такого процесу, а також педагогічні умови, дотримання яких з урахуванням проаналізованих підходів дозволить оптимізувати педагогічний процес індивідуально для кожної дитини.

\section{БІБЛІОГРАФІЧНИЙ СПИСОК:}

1. Алєксєєнко Т.Ф. Виховне середовище. Енциклопедія освіти / Акад. пед. наук України; гол. редактор В. Кремень. К.: Юрінком Інтер, 2008. С. 95-96.

2. Ананьев Б. Г. Задачи психологии искусства. Художественное творчество : сб. науч. трудов. Ленинград : Наука, 1982. С. 236-242.

3. Бех І.Д. Духовний розвиток особистості у фрокусі сучасного виховного процесу. Духовність особистості: методологія, теорія і практика. 2016. Вип. 6. С. 30-52.

4. Брушлинский А.В. Проблемы психологии субъекта. Москва : Педагогика, 2001. 304 с.

5. Винничук Р.В. Аксіологічний та культурологічний підходи як аспекти методології сучасної підготовки фрахівців у вищій школі. «Young Scientist» № 2.2 (54.2). February, 2018. C. 93-96.

6. Галеев Б. М. Историко-теоретический анализ концепций синестезии в мировой психологи. 
Вестник Российского гуманитарного научного фонда. 2005. № 1. С. 161-168.

7. Готсдинер А. Л. К проблеме многосторонних способностей. Вопросы психологии. 1991. № 4. C. 82-88.

8. Гризоглазова Т.І. Методика навчання гри на фортепіано : навчальний посібник. Київ : НПУ імені М. П. Драгоманова, 2018. 169 с.

9. Естетика : підручник / Л. Т. Левчук, Д. Ю. Кучерюк, В. І. Панченко; За заг, ред. Л. Т. Левчук. Київ : Вища школа, 1997. 399 с.

10. Зязюн І.А. Інтелектуально-творчий розвиток особистості в умовах неперервної освіти. Неперервна профресійна освіта: проблеми, пошуки, перспективи : монографрія / за ред. І.А. Зязюна. Київ: Віпол, 2000. С. 11-57.

11. Козир А. В. Теорія та практика фрормування профресійної майстерності вчителів музики в системі багаторівневої освіти : автореф. дис... д-ра пед. наук: 13.00.02; 13.00.04 / Нац. пед. ун-т ім. М.П. Драгоманова. Київ, 2009. 43 с.

12. Комаровська О.А. Художньо обдарована особистість: сутність, реалії, розвиток : монографрія. Івано-Франківськ, НAIP, 2014. 412 с.

13. Лі Хуйфан. Розвиток музикальності особистості як проблема науково-педагогічного знання. Молодь і ринок. № 5 (184), м. Дрогобич, 2020. C. $152-156$.
14. Рудницька О. П. Інтегративні зв'язки у викладанні предметів художньо-естетичного циклу. Початкова школа. 2001. № 5. С. 40-43.

15. Самопроектування особистості у дискурсивному просторі : монографрія / Н. В. Чепелєва, М. Л. Смульсон, О. В. Зазимко, С. Ю. Гуцол та ін. ; за ред. Н. В. Чепелєвої. Київ : Педагогічна думка, 2016. $232 \mathrm{c}$.

16. Ся Гаоян. Методика поліхудожньої підготовки майбутніх учителів музики у процесі вивчення музично-теоретичних дисциплін : автореф.... канд. пед. наук: 13.00.02. Київ, 2019. 20 с.

17. Теоретичні засади культурологічного підходу у підготовці педагога до виховної діяльності : монографрія / С.В. Машкіна, Т.П. Усатенко, Л.О. Хомич, Т.О. Шахрай. ІПООД НАПН України, 2016. 168 с.

18. Філіпчук Г.Г. Націєтворчість освіти : монографрія. Чернівці : Зелена Буковина, 2014. 400 с.

19. Цзя Ян. Воплощения представлений о синтезе искусств в творчестве современных китайских автором. Искусство и культура. 2016. № 2 (22). С. $80-86$.

20. Шевченко Г. П. Эстетическое воспитание в школе : учеб.-метод. пособие. Київ : Рад. шк., 1985. 144 с.

21. Юсов Б. П. Эстетическое развитие как интегрированный фрактор духовного фрормирования личности. Комплексное полихудожественное развитие школьников. Москва, 1994. Вып. 3. С. 8-27. 